\title{
Phenolic Content and Antioxidant Activity of Black Glutinous Rice Anthocyanin during Fermentation by Pediococcus pentosaceus N11.16
}

\author{
Nanik Suhartatik*, Akhmad Mustofa, Ponco Mursito \\ Agriculture Product Technology, Faculty of Industrial and Food Technology, \\ Slamet Riyadi University, Jl. Sumpah Pemuda No. 18, Surakarta, Middle Java 57136, Indonesia \\ *Email: n_suhartatik@yahoo.com
}

Submission: June 13, 2018; Acceptance: February 4, 2019

\begin{abstract}
Anthocyanin was developed into natural food colorant in microemulsion systems to improve their stability and readiness for food preparation. Anthocyanin has an antioxidant activity. The degradation of anthocyanin into small compound could increase the biological activity. Anthocyanin was extracted from black glutinous rice and prepared using food grade surfactant such as Tween 80, Tween 20, and Span 80. Microemulsion was then added into modified deMann Rogosa Sharp (MRS) medium as much as 5, 10, 15, 20 and 25 ppm. Lactic acid bacteria genus Pediococcus pentosaceus N11.16 were grown for 18-24 hours and were used as enzyme producers. This experiment was aimed to determine the stability of anthocyanin in microemulsion systems to enzymatic degradation. The modified MRS medium was added with microemulsion and incubated for $24 \mathrm{~h}$. Phenolic content remained stable during the fermentation process in all treatments, while the highest antioxidant activity was found in the sample with $20 \mathrm{ppm}$ of anthocyanin. Total acid-producing bacteria were also monitored during the incubation and the result showed that there was a decline in their growth. There was a significant change in the antioxidant activity during incubation.
\end{abstract}

Keywords: Anthocyanin; antioxidant activity of lactic acid bacteria; microemulsion

\section{INTRODUCTION}

Nowadays, public was concern to consume fresh food which more safe than processed food. Most processed foods were added by food additive to improve the physical, chemical, and sensory properties. In general, natural food colorants could become an alternative to develop healthier foods. Black glutinous rice (Oryza sativa var. glutinosa) is a pigmented rice consumed in Indonesia and majorly not as a staple food. It is a potential source of natural colorants such as anthocyanin which is also act as an antioxidant (Tananuwong \& Tewaruth, 2010); (Yodmanee, Karrila, \& Pakdeechanuan, 2011); (Nanik Suhartatik, Karyantina, et al., 2013). Consumption of food and beverages rich in anthocyanin can help to reduce risks of degenerative diseases such as atherosclerosis (Pascual-teresa, Moreno, \& García-viguera, 2010), heart disease, cancer (Kamiloglu, Capanoglu, Grootaert, \& van Camp, 2015), anti-inflammatory (Min, Ryu, \& Kim, 2010), and diabetes mellitus (Hogan et al., 2010);

Generally, anthocyanin considered as unstable (Shaheer et al., 2014).. High thermal treatment can cause degradation (Nanik Suhartatik, Karyantina, et al., 2013). Moreover, acidity also affects its stability. In acidic solution, anthocyanin is red and in high $\mathrm{pH}$ solution, it is blue in color. Anthocyanin is also affected by oxygen and ascorbic acid, where those factors can trigger hydrolysis of anthocyanin and it is degraded into simpler compounds such as phenols. Phenols have different antioxidant activity than anthocyanin. This derivative compound has better bioavailability than its glycosidic form. Another derivative form, anthocyanidin, is unstable in water and less soluble compared to anthocyanin.

Degradation rate of anthocyanin increases during processing and storage, especially when it involves heat that causes the opening of pyrylium ring and calcon 
structure as the first step of degradation. Anthocyanin gets degraded by heat when its calcon structure is transformed into coumarin glycoside that loses its B-ring. Aglycone sugar bond is more stable than other glycosidic bonds at pH 2-4 (Patras, Brunton, O'Donnell, \& Tiwari, 2010).

In previous researches by (Mustofa \& Suhartatik, 2018), production of anthocyanin microemulsion from black glutinous rice has been successfully achieved. Therefore, this research will observe degradation of anthocyanin during fermentation using Pediococcus pentosaceus N11.16. The isolate was lactic acid bacteria isolated from traditional fermented food in Indonesia and has the ability to degrade anthocyanin in black glutinous rice into simpler compounds with better antioxidant activity (N Suhartatik, Cahyanto, Rahardjo, Miyashita, \& Rahayu, 2014). The objective of this research was to study the changes in phenolic content and antioxidant activity during enzymatic degradation process using Pediococcus pentosaceus N11.16. Enzymatic degradation or consider as fermentation process of anthocyanin was important to study the effect to the antioxidant activity. Enzymatic degradation was quietly different from chemical degradation which more cleavage the bond randomly. The effect of enzymatic degradation to the functional properties of anthocyanin from black glutinous rice extract never study before.

\section{MATERIALS AND METHODS}

The lactic acid bacteria Pediococcus pentosaceus N11.16 was obtained from Food and Nutrition Culture Collection (FNCC) Centered Studied for Food and Nutrition, Universitas Gadjah Mada, Indonesia. Chemicals needed were distilled water, buffer solutions prepared at $\mathrm{pH} 1$ and $\mathrm{pH} 4, \mathrm{CaCO}_{3}, \mathrm{NaCl}$, Folin Ciocalteau (Oxoid, Jakarta, Indonesia), $\mathrm{Na}_{2} \mathrm{CO}_{3}$, agar, yeast extract (Merck, Jakarta, Indonesia), peptone, Tween 80 (Oxoid, Jakarta, Indonesia), ammonium citrate, Sodium acetate, Magnesium sulfate (Merck, Jakarta, Indonesia), Manganese sulfate (Merck, Jakarta, Indonesia), dipotassium phosphate (Merck, Jakarta, Indonesia), and cellobiose (Merck, Jakarta, Indonesia), which were supplied by a local company at analytical grade.

Black glutinous rice from local market was grind in to 60 mesh and dissolved into $70 \%$ of acidified ethanol ( $1 \%$ acetic acid). Two hundred gram of black glutinous rice flour was added with acidified ethanol till $1000 \mathrm{ml}$ for $15 \mathrm{~min}$. Black glutinous rice flour was extracted twice and the filtrate were vacuum evaporated in $60^{\circ} \mathrm{C}$ and $60 \mathrm{rpm}$ till the all ethanol removed. Anthocyanin from black glutinous rice flour extract were stored in -4 ${ }^{\circ} \mathrm{C}$ till used.

Microemulsions are made from a mixture of surfactant types of hydrophilic surfactants (Tween 20 and Tween 80) and lipophilic (Span 80). Mixture of oilsurfactant $(15: 85 \mathrm{v} / \mathrm{v})$ with a ratio of surfactant Tween 80: Span 80: Tween 20 = 92: 5.5: 2.5 ( $\%$ v / v) added water drop by drop and stirred using a magnetic stirrer at a temperature of $70 \pm 5^{\circ} \mathrm{C}$ to a moisture content of $65 \%$, so that the solution looks transparent (Cho et al. 2008).

Five concentrations of anthocyanin were added into modified MRS medium (Oxoid, Jakarta, Indonesia): 5, 10, 15, 20 and $25 \mathrm{ppm}$. Modified MRS consist of: $1 \%$ peptone, $0.5 \%$ yeast extract, $0.1 \%$ Tween 80 , $0.2 \%$ ammonium citrate, $0.5 \%$ sodium acetate, $0.01 \%$ magnesium sulfate, $0.005 \%$ manganese sulfate, $0.2 \%$ dipotassium phosphate, and $1 \%$ cellobiose as a replacement for glucose. Cellobiose was used to induce production of the $\beta$-glucosidase enzyme. Only $10 \%$ of cellobiose (Adsul, Khire, Bastawde, \& Gokhale, 2007; Suhartatik et al., 2014) was added in order to trigger production of the enzyme that can break anthocyanin into glucose and anthocyanidin. The medium were then homogenized and sterilized using autoclave in $121^{\circ} \mathrm{C}$ for 15 min before inoculation.

The biomass was sub-cultured by growing it in MRS medium for $18-24 \mathrm{~h}$. Biomass was collected by centrifuging the medium at $3500 \mathrm{rpm}$ for $15 \mathrm{~min}$ and discarding the supernatant. The biomass was then washed with $0.85 \% \mathrm{NaCl}$ and re-centrifuged. Freshly prepared biomass was always used in the experiment. Biomass prepared was next added with $5 \mathrm{~mL}$ of modified MRS medium and anthocyanin extract at the set concentrations. Mixture was then homogenized and analyzed for its anthocyanin (Eisele et al., 2005) and phenolic contents (Qiu, Liu, \& Beta, 2010), antioxidant activity (Yen \& Chen, 1995), and total acid-producing microorganisms at $0,2,4,8,12,16,20$, and $24 \mathrm{~h}$ using direct pour plate count method. Data collected from tree replications were put into graphs depicting changes in biomolecules in fermentation medium.

\section{RESULTS AND DISCUSSION}

\section{Anthocyanin Content}

There are many factors affecting natural anthocyanin content in a sample such as species, the environment, and agricultural practices. Raw materials go through heat processing in order to make them edible and this process affects the anthocyanin content of the product. Any thermal processing involves heating at 50 
$-100{ }^{\circ} \mathrm{C}$ can reduce the anthocyanin content (Patras et al., 2010).

Level and duration of heating has strong effect on stability of anthocyanin. In elderberry fruits, anthocyanin is highly sensitive to heating, where after $3 \mathrm{~h}$ of heating at $95{ }^{\circ} \mathrm{C}$, only $50 \%$ of the pigment is left. Several studies stated the logarithmic relationships between degradation of anthocyanin and the arithmetic of temperature increase. Different cooking methods affect anthocyanin content differently, e.g. blanching, boiling and steaming cabbage caused loss of its anthocyanin content for 59,41 , and $29 \%$, respectively (Patras et al., 2010).

Like other polyphenols, anthocyanin degrades enzymatically by polyphenol oxidase. This enzyme can be inactivated with mild heating. Moreover, copigmentation also affects anthocyanin stability, for instance anthocyanin in red cabbage is more stable under heat treatment compared to grapes and elderberry due to protection given by flavylium co-pigmentation. Anthocyanin stability is also affected by $\mathrm{pH}$, for example in black carrot (Patras et al., 2010). Amount of anthocyanin added into modified MRS medium and duration of incubation can affect anthocyanin content in sample (Figure 1).

From Figure 1, it can be seen that anthocyanin content at $0 \mathrm{~h}$ was the highest in sample with 25 ppm addition of extract and the lowest was in sample added with $5 \mathrm{ppm}$ extract. At $0 \mathrm{~h}$, there has not been a degradation process taking place. At the second hour, anthocyanin content increased in average since $P$. pentosaceus $\mathrm{N} 11.16$ was still in adaptation stage and it did not start any degradation process. However, at $4 \mathrm{~h}$, the microorganism had adapted well with the medium and it started to degrade anthocyanin into simpler compounds.

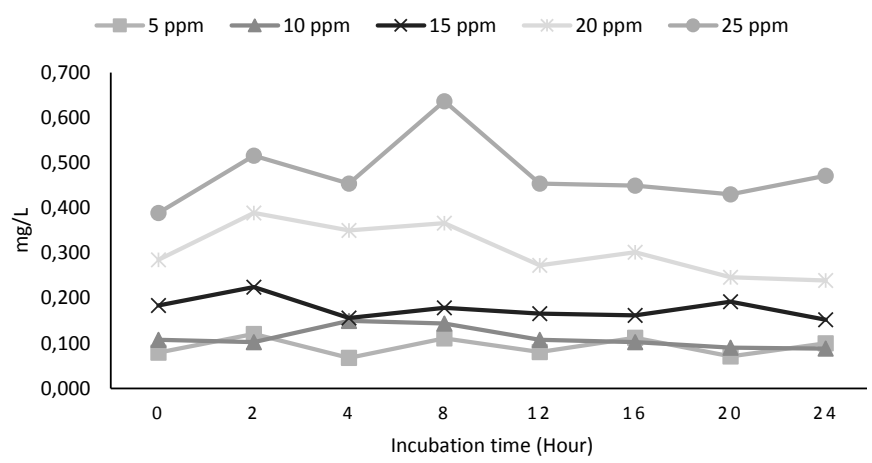

Figure 1. Anthocyanin content of modified MRS medium added with extract of black glutinous rice and fermented with P. pentosaceus N11.16
Anthocyanin content of samples increased after $8 \mathrm{~h}$ since $P$. pentosaceus N11.16 slowed down its enzyme production, but after 12 hours of incubation, the productivity increased significantly. It was because the microorganism in the lag phase and degraded most anthocyanin and phenols, before it entered the stationary period where anthocyanin content stayed the same.

Concentration of anthocyanin extract added into modified MRS medium and the length of incubation period could affect growth and productivity of $P$. pentosaceus N11.16 in adaptation, lag, and stationary phases, which eventually affected degradation rate. Variation in concentration of anthocyanin in the medium resulted in different effects on growth rate and anthocyanin degradation.

Based on Figure 1, the best result was given by addition of $15 \mathrm{ppm}$ anthocyanin since this treatment resulted in high and stable anthocyanin content, apart from its economical reasons. Similar to other natural colorants, anthocyanin is relatively unstable and it tends to be more stable in acidic condition. Color and stability of anthocyanin is highly affected by the sugar and acyl groups in its aglycone(Fennema, 2017). Anthocyanin is degraded through several possible mechanisms that change its color into colorless or brown soluble product or insoluble product. Main factors affecting degradation of anthocyanin is the structure and concentration of anthocyanin, $\mathrm{pH}$, temperature, oxygen availability, and light (Jackman \& Smith, 1996).

\section{Antioxidant Activity of Modified MRS Medium}

Black glutinous rice is a type of product having high antioxidant. This study used the help of $P$. pentosaceus N11.16 to degrade anthocyanin into other forms of antioxidant that have good bioavailability. Differences in antioxidant activity can be seen in Figure 2 .

Figure 2 shows that addition of 5 and $10 \mathrm{ppm}$ of anthocyanin extract resulted in almost similar antioxidant activity that was more stable compared to other treatments. Five ppm anthocyanin addition was slightly better than treatment with $10 \mathrm{ppm}$ anthocyanin since with less addition; it could still result in high and stable antioxidant activity, which is considered beneficial economically.

Addition of anthocyanin can be increased up to 10 ppm if stronger color is desired, where at this level of addition, the antioxidant activity was high and stable. Addition of more than 10 ppm, such as 15, 20, and 25 ppm, were not suggested since the results showed that they gave unstable antioxidant activity and they were also more costly. 


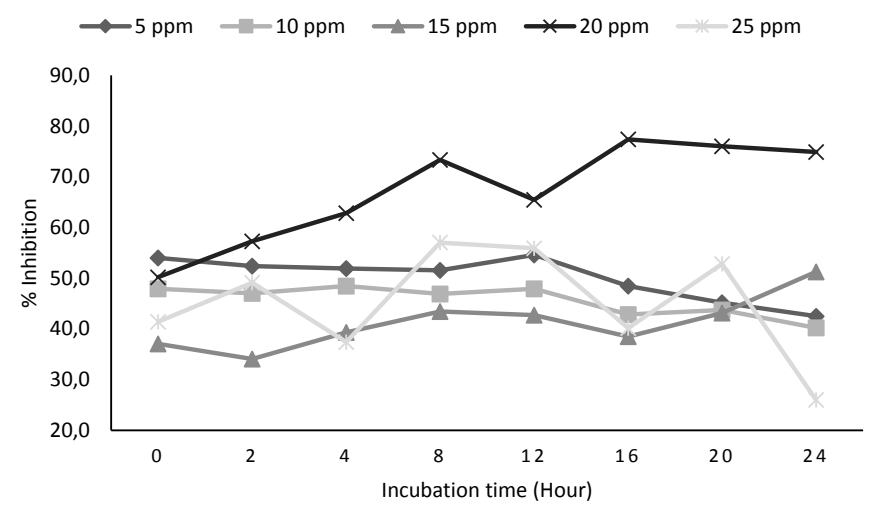

Figure 2. Antioxidant activity of modified MRS medium added with P. pentosaceus N11.16 and anthocyanin extract from black glutinous rice

Antioxidant activity increased significantly in modified MRS medium with addition of $20 \mathrm{ppm}$ anthocyanin extract. This result indicates that at that level of addition, anthocyanin would be degraded into simpler compounds with high antioxidant activity. To gain maximum benefits, this addition level is suggested to be used in food production.

\section{Phenolic Content}

Phenolic are produced in plants through the path of cyclic and phenyl propanoic acid metabolism. Phenolic compounds have been known to have various biological effects such as antioxidant activity through reducing mechanisms, free radical scavenger, metal chelating, singlet oxygen stabilizer and electron donors (Ghasemzadeh \& Jaafar, 2011). Phenols are antioxidants when present at low concentrations, whereas at high concentrations the phenolic activity of antioxidants will disappear and turn into pro-oxidants.

Phenolic was a product of degradation of anthocyanin by $P$. pentosaceus N11.16. Phenolic was a flavonoid that has important roles in health, since it has the ability to fight against free radicals, diabetes, and cancer. Changes in phenolic content are affected by many factors, such as variation in level of addition of anthocyanin extract into the modified MRS medium and length of incubation period. From the previous research has reported that lactic acid bacteria, Lactobacillus plantarum Mut 7 and Pediococcus acidilactici N11.16 have the ability to cut anthocyanin glycosides using MRS medium without sugar and yeast extract treatment methods (Nanik Suhartatik, Cahyanto, Raharjo, \& Rahayu, 2013)(Nanik Suhartatik, Karyantina, Cahyanto, Raharjo, \& Rahayu, 2014).

Table 1 shows the effect of anthocyanin extract in modified MRS medium at different incubation periods on total phenolic content. Every treatment resulted in different phenolic content that tended to be unstable, except in sample with $10 \mathrm{ppm}$ anthocyanin, which was more stable compared to other treatments.

From the Figure 3, it can be seen that total acid producing bacteria count was relatively unstable. Incubation period and dilution factor highly affected the total acid producers. Sample added with 15 $\mathrm{ppm}$ anthocyanin extract showed negative growth of microorganisms between 0 to $16 \mathrm{~h}$ of incubation time. This could be due to many factors such as yeast contamination, overheating of medium that caused death of bacteria, as well as human error.

The enzyme $\beta$-glucosidase ( $\beta$-D-glucoside glucohydrolase, EC 3.2.1.21) is a group of enzymes (consisting of 88 families) that have the ability to hydrolyze several types of glycosides, including aryl-and alkyl$\beta$-D-glycoside. Physiological function of $\beta$-glucosidase depends on its source (plant, fungi, animal, or bacteria) and substrate characteristics (Bhatia, Mishra, \& Bisaria, 2002). Beta glucosidase produced from bacteria has been developed to hydrolyzed glycosidic compound with the final objective to increase its bioavailability (Jeon, Suk, Ji, \& Hwang, 2002). Pyo, Lee, \& Lee (2005) used lactic acid bacteria to produce $\beta$-glucosidase as a starter culture in fermentation of soy milk. The isolated lactic acid bacteria used came from the species $L$. plantarum and $L$. delbrueckii subsp. Lactis. Results showed that

Table 1. Phenolic content of modified MRS medium with the addition of $P$. pentosaceus N11.16

\begin{tabular}{|c|c|c|c|c|c|c|c|c|}
\hline \multirow{2}{*}{$\begin{array}{l}\text { Anthocyanin } \\
\text { addition }\end{array}$} & \multicolumn{8}{|c|}{ Total phenolic content (ppm) for MRS medium with incubation period $(\mathrm{h})$} \\
\hline & 0 & 2 & 4 & 8 & 12 & 16 & 20 & 24 \\
\hline $5 \mathrm{ppm}$ & $89.3 \pm 0.18^{\mathrm{a}}$ & $120.3 \pm 5.35^{b}$ & $90.0 \pm 0.02^{\mathrm{a}}$ & $116.7 \pm 0.08^{\mathrm{a}}$ & $88.7 \pm 0.59^{a}$ & $91.5 \pm 0.78^{\mathrm{a}}$ & $93.3 \pm 1.66^{\mathrm{a}}$ & $119.0 \pm 1.94^{\mathrm{ab}}$ \\
\hline $10 \mathrm{ppm}$ & $103.1 \pm 0.27^{\mathrm{ab}}$ & $97.0 \pm 5.66^{\mathrm{a}}$ & $135.9 \pm 0.23^{\mathrm{cd}}$ & $136.9 \pm 0.69^{b}$ & $103.5 \pm 0.48^{\mathrm{b}}$ & $102.1 \pm 0.08^{\mathrm{a}}$ & $103.5 \pm 0.95^{\mathrm{a}}$ & $105.1 \pm 0.61^{\mathrm{a}}$ \\
\hline $15 \mathrm{ppm}$ & $118.6 \pm 0.27^{\mathrm{bc}}$ & $184.5 \pm 7.72^{c}$ & $119.3 \pm 3.45^{\mathrm{bc}}$ & $117.8 \pm 0.38^{\mathrm{a}}$ & $117.0 \pm 0.38^{c}$ & $121.8 \pm 0.46^{b}$ & $152.8 \pm 3.28^{c}$ & $114.3 \pm 0.57^{\mathrm{ab}}$ \\
\hline 20 ppm & $126.9 \pm 8.63^{c}$ & $168.6 \pm 0.63^{c}$ & $169.2 \pm 1.68^{\mathrm{e}}$ & $183.3 \pm 4.00^{c}$ & $123.0 \pm 4.21^{c}$ & $156.2 \pm 0.84^{c}$ & $128.6 \pm 0.21^{b}$ & $124.2 \pm 3.37^{b}$ \\
\hline 25 ppm & $133.3 \pm 2.74^{c}$ & $124.2 \pm 1.68^{b}$ & $148.4 \pm 5.26^{d}$ & $211.3 \pm 5.89^{d}$ & $163.8 \pm 1.26^{\mathrm{d}}$ & $142.3 \pm 0.84^{c}$ & $168.8 \pm 2.53^{c}$ & $150.7 \pm 2.95^{c}$ \\
\hline
\end{tabular}

Note: Value with different notation in the same column has a significant differences at $5 \%$ 


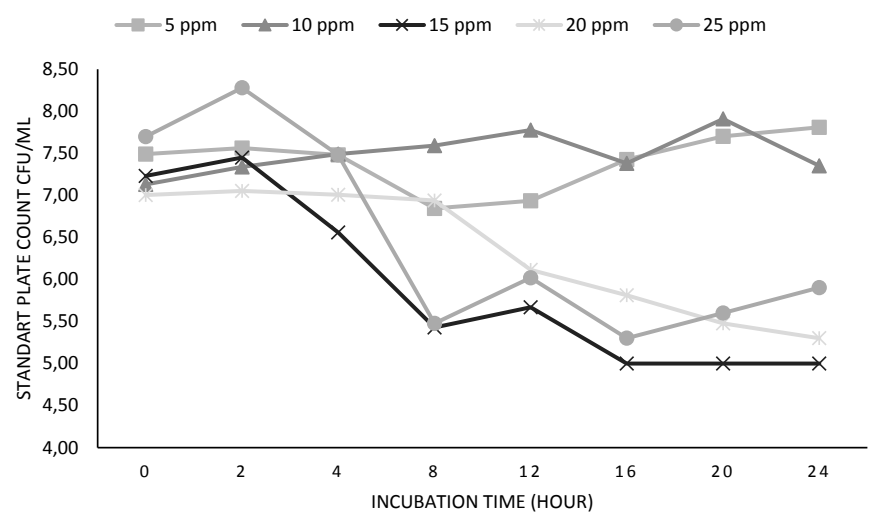

Figure 3. Total acid-producing bacteria in modified MRS medium with the addition of $P$. pentosaceus N11.16

aglycones increased 7 times from initial concentration and it was also found that there was a correlation between cell growth and the activity of $\beta$-glucosidase.

The first group of enzyme can hydrolyze $\beta$-glycosidic bond in cellobiose lactose $\beta \rho$-nitrophenyl glucoside, $\beta \rho$-nitrophenyl galactoside, $\beta \rho$-nitrophenyl fructoside and other substrates with almost similar structure. The second group pays specific attention on glycosyl $\beta$-glucoside, which can only hydrolyze substrates like cellobiose and lactose. The third group can only hydrolyze aryl or alkyl $\beta$-glucoside (Terra \& Ferreira, 1994).

The more dilution performed, the lower the number of acid-producing bacteria that grow. In terms of length of incubation period, longer incubation period causes less growth of lactic acid bacteria. Anthocyanin content added into modified MRS also affected growth of the bacteria, where the more anthocyanin added, the lower the growth rate of the acid-producing bacteria.

\section{CONCLUSIONS}

From this study it can be concluded that anthocyanin is degraded into simpler molecules by Pediococcus pentosaceus N11.16. Variation in anthocyanin content added into modified MRS medium and length of incubation strongly affect to the bacteria's adaptation, growth and productivity. P. pentosaceus N11.16 degrades anthocyanin resulting in differences in anthocyanin content, antioxidant activity, phenolic content, and total count of bacteria. Addition of $20 \mathrm{~mL}$ anthocyanin gave better results compared to other treatments, since with this treatment there were high levels of anthocyanin, antioxidant, and phenols. Moreover, this treatment can also be considered less costly.

\section{ACKNOWLEDGEMENT}

Special thanks to General Ministry of Research, Technology and Higher Education for the funding through Hibah Bersaing 2017 and Team Research of Anthocyanin Microemulsion.

\section{CONFLICT OF INTEREST}

There was no conflict interest of the article publication.

\section{REFERENCE}

Adsul, M., Khire, J., Bastawde, K., \& Gokhale, D. (2007). Production of Lactic Acid from Cellobiose and Cellotriose by Lactobacillus delbrueckii Mutant Uc-3, 73(15), 50555057. https://doi.org/10.1128/AEM.00774-07.

Bhatia, Y., Mishra, S., \& Bisaria, V. S. (2002). Microbial betaGlucosidase: Cloning, Properties, and Applications. Critical Reviews in Biotechnology, 22(4), 375-407.

Eisele, T., Giusti, M. M., Hofsommer, H., Koswig, S., Krueger, D. A., Kupina, S., ... Wightman, J. D. (2005). Determination of Total Monomeric Anthocyanin Pigment Content of Fruit Juices, Beverages, Natural Colorants, and Wines by the pH Differential Method: Collaborative Study, 12691278.

Fennema, O. R. (2017). Food Chemistry (3rd ed.). New York: Marcell Dekker. Inc.

Ghasemzadeh, A., \& Jaafar, H. Z. E. (2011). Antioxidant potential and anticancer activity of young ginger (Zingiber officinale Roscoe) grown under different $\mathrm{CO} 2$ concentration. Journal of Medicinal Plants Research, 5(14), 3247-3255. Retrieved from http:// www.academicjournals.org/JMPR/abstracts/abstracts/ abstracts2011/18July/Ghasemzadeh and Jaafar.htm.

Hogan, S., Zhang, L., Li, J., Sun, S., Canning, C., \& Zhou, K. (2010). Antioxidant rich grape pomace extract suppresses postprandial hyperglycemia in diabetic mice by specifically inhibiting alpha-glucosidase, 1-9.

Jackman, R. L., \& Smith, J. L. (1996). Anthocyanins and betalains. Natural Food Colorants, 244-309. https://doi. org/10.1007/978-1-4615-2155-6_8.

Jeon, A., Suk, K., Ji, G. E., \& Hwang, I. K. (2002). Assay of ??-glucosidase activity of bifidobacteria and the hydrolysis of isoflavone glycosides by Bifidobacterium sp. Int-57 in soymilk fermentation. Journal of Microbiology and Biotechnology, 12(1), 8-13.

Kamiloglu, S., Capanoglu, E., Grootaert, C., \& van Camp, J. (2015). Anthocyanin absorption and metabolism by human intestinal Caco-2 cells-A review. International 
Journal of Molecular Sciences, 16(9), 21555-21574. https://doi.org/10.3390/ijms160921555.

Min, S., Ryu, S., \& Kim, D. (2010). International Immunopharmacology Anti-in fl ammatory effects of black rice, cyanidin-3-0- $\beta$ - D -glycoside, and its metabolites, cyanidin and protocatechuic acid. International Immunopharmacology, 10(8), 959-966. https://doi.org/10.1016/j.intimp.2010.05.009.

Mustofa, A., \& Suhartatik, N. (2018). Stabilitas Minuman Isotonik Antosianin Beras Ketan Hitam dengan Senyawa Kopigmentasi Ekstrak Bunga Belimbing ( Averrhoa carambola ) Stability of Isotonic Drink Made from Black Glutinous Rice Extract Anthocyanin with Starfruit ( Averrhoa carambola ) Flower, 38(1), 1-6.

Pascual-teresa, S. De, Moreno, D. A., \& García-viguera, C. (2010). Flavanols and Anthocyanins in Cardiovascular Health : A Review of Current Evidence, 1679-1703. https://doi.org/10.3390/ijms11041679.

Patras, A., Brunton, N. P., O'Donnell, C., \& Tiwari, B. K. (2010). Effect of thermal processing on anthocyanin stability in foods; mechanisms and kinetics of degradation. Trends in Food Science and Technology, 21(1), 3-11. https:// doi.org/10.1016/j.tifs.2009.07.004.

Pyo, Y. H., Lee, T. C., \& Lee, Y. C. (2005). Enrichment of bioactive isoflavones in soymilk fermented with ??-glucosidase-producing lactic acid bacteria. Food Research International, 38(5), 551-559. https://doi. org/10.1016/j.foodres.2004.11.008.

Qiu, Y., Liu, Q., \& Beta, T. (2010). Antioxidant properties of commercial wild rice and analysis of soluble and insoluble phenolic acids. Food Chemistry, 121(1), 140147. https://doi.org/10.1016/j.foodchem.2009.12.021.

Shaheer, C. A., Hafeeda, P., Kumar, R., Kathiravan, T., Kumar, D., \& Nadanasabapathi, S. (2014). Effect of thermal and thermosonication on anthocyanin stability in jamun (Eugenia jambolana) fruit juice. International Food Research Journal, 21(6), 2189-2194.

Suhartatik, N., Cahyanto, M. N., Rahardjo, S., Miyashita, M., \& Rahayu, E. S. (2014). Isolation and identification of lactic acid bacteria producing $\beta$ glucosidase from Indonesian fermented foods. International Food Research Journal, 21(3), 937-942. Retrieved from http://www.ifrj.upm. edu.my.
Suhartatik, N., Cahyanto, M. N., Raharjo, S., \& Rahayu, E. S. (2013). Antioxidant Activity of Anthocyanin of Black Glutinous Rice During Fermentation. Jurnal Teknologi Dan Industri Pangan, 24(1), 115-119. https://doi. org/10.6066/jtip.2013.24.1.115.

Suhartatik, N., Karyantina, M., Cahyanto, M. N., Raharjo, S., \& Rahayu, E. S. (2014). Karakteristik Fermentatif Medium deMann Rogosa Sharpe (MRS) Antosianin Beras Ketan Hitam (Oryza sativa var. glutinosa) Menggunakan Pediococcus pentosaceus N11.16. agriTECH, 34(3), 291-297.

Suhartatik, N., Karyantina, M., Mustofa, A., Cahyanto, M. N., Raharjo, S., \& Rahayu, E. S. (2013). Stability of Anthocyanins Extracted from Black Glutinous Rice (Oryza sativa var. glutinosa) during Heating and Storage Process. agriTECH 33(4), 384-390.

Tananuwong, K., \& Tewaruth, W. (2010). Extraction and application of antioxidants from black glutinous rice. LWT - Food Science and Technology, 43(3), 476-481. https://doi.org/10.1016/j.lwt.2009.09.014.

Terra, W. R., \& Ferreira, C. (1994). Insect digestive enzymes: properties, compartmentalization and function. Comparative Biochemistry and Physiology, 109, 1-62.

Withers, S. G., \& Street, I. . (1988). Identification of a covalent a-D-glucopyranosyl enzyme intermediate formed on a $\beta$ glucosidase. Journal of American Chemistry and Society, 110, 8551-8553.

Yen, G.-C., \& Chen, H.-Y. (1995). Antioxidant Activity of Various Tea Extract in Their Antimutagenicity. Journal of Agricultural and Food Chemistry, 43, 27-32.

Yodmanee, S., Karrila, T. T., \& Pakdeechanuan, P. (2011). Physical, chemical and antioxidant properties of pigmented rice grown in Southern Thailand. International Food Research Journal, 18(3), 901-906. 